\title{
Sustainable Awareness: Strategic Plan of Waste Management for a Brazilian Company
}

\author{
Ana Claudia Machado Padilha ${ }^{1}$, Elaine Pandolfo Brustolin ${ }^{1}$, Juliana Birkan Azevedo ${ }^{1} \&$ Paloma de Mattos \\ Fagundes $^{2}$ \\ ${ }^{1}$ University of Passo Fundo, Brazil \\ ${ }^{2}$ Federal University of Santa Maria, Brazil \\ Correspondence: Ana Claudia Machado Padilha, University of Passo Fundo, Brazil. E-mail: anapadilha@upf.br
}

Received: January 20, 2015 Accepted: January 28, 2015 Online Published: April 27, 2015

doi:10.5539/par.v4n1p38

URL: http://dx.doi.org/10.5539/par.v4n1p38

\begin{abstract}
This study presents a strategic plan of waste management for Alban, Crema \& Cia Ltda., a company located in the south of Brazil, since it must adapt to the needs of society, fulfilling the law to ensure its market positioning. In order to achieve such objective, an exploratory qualitative study was conducted through an interpretive analysis of a questionnaire. The main result of the study was that it was observed that even with a well-defined structure and a remarkable concern with environmental legislation, it is necessary to develop awareness mechanisms of managers and employees. Despite the entrenched organizational culture and little knowledge of issues related to sustainability, the company is looking forward to moving to this direction. Regarding so, the company will develop methods to manage the waste produced through awareness and improving employees' work environment, seeking new opportunities and customers through implemented improvements.
\end{abstract}

Keywords: waste, legislation, market, awareness

\section{Introduction}

The diversity of industrial activities leads to the generation of various types of waste that can contaminate the environment if not handled correctly. The vast majority of companies have been facing difficulties in relation to the environmental agencies, due to the need to meet the requirements, forcing the industry to develop and implement management processes in a way that meets the demand from its customers and comply with active environmental laws. With these systems, entrepreneurs can verify that an environmentally friendly approach in the management of their processes directly reflects in productivity, quality and consequently, brings about better financial results.

A trend that the environmentally friendly consumption becomes increasingly practiced by the people can be observed, because they began to worry more about the quality of life and, consequently, about the environment. Kraemer (2005) pleads that environmental management has become a requirement for companies as they are increasingly concerned about having an environmentally friendly and positive image to its consumers, who demand clean products, and the responsible marketing has been a largely used strategy.

In Brazil, environmental legislation is significantly changing the economy and has very strict regulations. Moreover, the fact that consumers are more aware and demanding, companies that do not act in accordance with the law may have significant losses on cash and the image can be damaged, so it has been observed the importance of Environmental Management.

The Environmental Management System is a process aimed to solve or prevent the problems of an environmental nature, with the goal of sustainable development. According to Fischer and Schot (1993), the concern about the environment must involve government, companies, society and academy, but mainly manufacturers. As stated in ISO 14001, an Enviromental Management System can be defined as the part of the management system that includes organizational structure, responsibilities, practices, procedures, processes and resources for implementing, developing, reviewing and maintaining the environmental policy of the company. Ceruti and Silva (2009) admit that this sytem is voluntary, there is no legal term that obligates any Corporation to incorporate it, but the current market has been so demanding that the spontaneous concern becomes a competitive strategy. 
The implementation of an Environmental Management System for a company assumes and requires a strong commitment of its managers and employees with the environment, and it is very important for the company to adapt to the environmental standards. However, managing a process, through this tool enables numerous gains in productivity and quality, beyond the satisfaction of the people directly involved in the process, since they learn that it is always possible to do better and feel the evolution of the quality of their services and the most important in this process: the client relies much more on the company and its products. Acting in an environmentally responsible manner is still a differentiator among companies, especially in the competitive market. This differential will become a prerequisite and the sooner companies realize this new reality, the greater the chance of staying in the market.

Every industrial activity generates waste, unwanted byproducts that may not always be reused in the manufacturing process. These wastes must be properly managed and designed to prevent damage to the environment and the population to prevent the company of suffering an environmental penalty (Corazza, 2003).

In this sense, the study aims to propose actions for the internal organization and awareness of professionals to enable better management of waste in Alban, Crema \& Cia Ltda. company. The printing industry Alban, Crema \& Cia Ltda. headquartered since 1960 in the city of Serafina Corrêa, in the south of Brazil, and produces customized printed products, with strong performance in the regional market. Given the portfolio of prospects and concern for the environment and people, the company needs to manage the waste produced by it, since it lacks an Environmental Management System with appropriate monitoring.

Thus, the internal management can contribute to the correct identification, separation, selection and destination of waste that the company produces, which will allow greater visibility of local storage, cost reduction and employees' well-being at work.

\section{Environment and Environmental Management}

Society as a whole is responsible for the preservation of the environment, then it is necessary to act in the best possible way not to modify it in a negative way, as this will have consequences for the quality of life of present and future generations.

According to National Environment Council - CONAMA, Resolution 306:2002 the environment is the set of conditions, laws, influences and interactions of physical, chemical, biological, social, cultural and urban, which allows houses and governs life in all its forms. An organization is responsible for the environment that surrounds it, and must therefore respect it, act as non-polluting and comply with relevant legislation and standards (ISO 14001).

When there is any kind of production, distribution or consumption, the process always demands on the environment. That is, in case of inputs the environment works as the resource and in case of output to the environment as waste (Coe et al., 2008).

Environmental management studies the different ways of life and also the interaction of humans with nature, and Nilsson (1998) highlights that it involves planning, organizing, and guiding the company to achieve specific environment goals. An important aspect of environmental management is that its introduction requires decisions at the highest levels of management and, therefore, sends a clear message to the organization that it is a corporate commitment, so according to the author, it can also become an important tool for organizations in their dealings with consumers, the general public, insurance companies and governmental agencies.

Dias (2006) explains that Environmental Management is the term used to name the business management that is oriented to avoid problems for the environment, whose main goal is to prevent that the environmental effects exceed the carrying capacity of the environment where the organization is, which, in other words is to obtain a sustainable development. Donaire (1995) and Valle (1995) agree that the influence of the environmental issue in the world of business is undeniable and that companies that enjoy this reality may not only gain economically and strategically but also avail themselves of many opportunities in the market.

The environmental management is an integral part of the overall management system of the organization. The formulation of an Environmental Management System is an interactive and ongoing process. The structure, responsibilities, practices, procedures, processes and resources for the implementation of policies, objectives and targets can be coordinated with other efforts in other administrative areas. In this aspect, it is understood that it is an integral part of total management of an organization, which recognizes the quality of its environmental performance as a key factor in its ability to thrive, devising a system for identify, examine and systematically assess the environmental changes caused by aspects or features of products, services and activities.

Figueiredo (1996) comments that the environmental management systems are focused on the context of the men 
in their habitat. Within this approach, it can be identified as an integrated activity so that, for an environmental performance within the standards established for the legislation on the environment, one must basically meet the principles presented in Table 1.

Table 1. Principles to obtain an environmental performance

\begin{tabular}{ll}
\hline Internally the process & External to the process \\
\hline $\begin{array}{l}\text { Training: ensuring perfect harmony within the } \\
\text { process; }\end{array}$ & $\begin{array}{l}\text { Treating effluent: ensuring the quality of natural } \\
\text { resources (water, air and soil) }\end{array}$ \\
$\begin{array}{l}\text { Keep monitoring the systems: enabling work in safe } \\
\text { conditions; }\end{array}$ & $\begin{array}{l}\text { Inform: notifying the population about the risk level of } \\
\text { activity undertaken } \\
\text { Monitor external systems: avoiding environmental } \\
\text { damage } \\
\text { health of technicians. }\end{array}$ \\
& $\begin{array}{l}\text { Minimize environmental impact: developing activities } \\
\text { to eliminate or minimize the industrial requirements. }\end{array}$ \\
\hline
\end{tabular}

Source: Adapted from Figueiredo (1996).

An effective Enviromental Management System can also be used to, among other things, demonstrate to customers the environmental concern of the company, maintaining good relationships with the community and with non-governmental organizations, ensuring access to financing, obtaining insurance at lower costs, reduce labor causes, reducing consumption of materials and energy, and improving relationships with government agencies. To Wildmer (1997), the main goal of an environmental management system should be to protect the environment and human health impacts that are generated by the activities, products or services of an organization.

Environmental auditing, life cycle assessment, environmental impact studies, environmental management system, environmental reporting, environmental labeling, environmental risk management, environmental education are some of the many tools that companies can avail to achieve environmental goals (Barbieri, 2004).

Businesses are established with some definite purposes, but primarily for profit. A profitable venture and proper environmental management, demonstrate that companies have reduced their costs because they consume less water, by the rational use; they also consume less energy by reducing waste; use less raw material by the rationalization of its use; generate less waste and leftovers by the appropriateness of the use of inputs; and reuse, recycle or sell waste whenever possible; spending less on pollution control.

When companies reduce their costs, they increase their competitiveness, and so they can charge less from consumers. In addition, they gain new customers by demonstrating social responsibility, as consumers are increasingly aware and well informed about the environmental effects and ecologically friendly production processes, as well as they are willing to pay more for brands associated to a positive attitude towards the protection of the environment.

\subsection{Waste Classification and Category}

The concern toward the environment is not fashionable or even opportunism, it is a matter of survival for businesses. Agreeing with the same idea, Valle (1995) adds that environmental policy should not be seen as a burden, but as an important tool for the success of the company that, in addition to complying with the law, wants to establish their good image.

All industrial activities generate waste, unwanted byproducts that may not always be reused in the manufacturing process. These wastes must be properly managed and designed to prevent damage to the environment and to the population, preventing the company suffers an environmental penalty (Corazza, 2013). Zeng et al. (2010) warn that the conventional solid waste management contribute to the global warming phenomenon, due to the rising of emission of greenhouse gases (GHGs) in Earth's atmosphere.

Industrial residues correspond to the residues generated in the various types of processing industries. Depending on the dangerousness offered by some of these wastes, the following grouping is proposed by Associação Brasileira de Normas Técnicas - Norma Brasileira (ABNT-NBR) 10004 (2004):

Waste Class I - Dangerous: by their characteristics of flammability, corrosivity, reactivity, toxicity and 
pathogenicity, they may present risks to public health, causing or contributing to increased mortality or submitting adverse environmental effects when handled or disposed improperly. .

Waste Class II - Not Dangerous: they do not exhibit characteristics of dangerousness. They are waste from restaurants, recyclable, rubber.

Waste Class II A - Not Inert: Wastes that present biodegradation or water solubility.

Waste Class II B - Inert: Any waste submitted to a contact with distilled or deionized water at room temperature, do not have any of its constituent solubilized, i.e., is a residue remaining on its property even in contact with distilled water .

In this respect, Figure 1 complements the discussion by addressing the flowchart of waste classification.

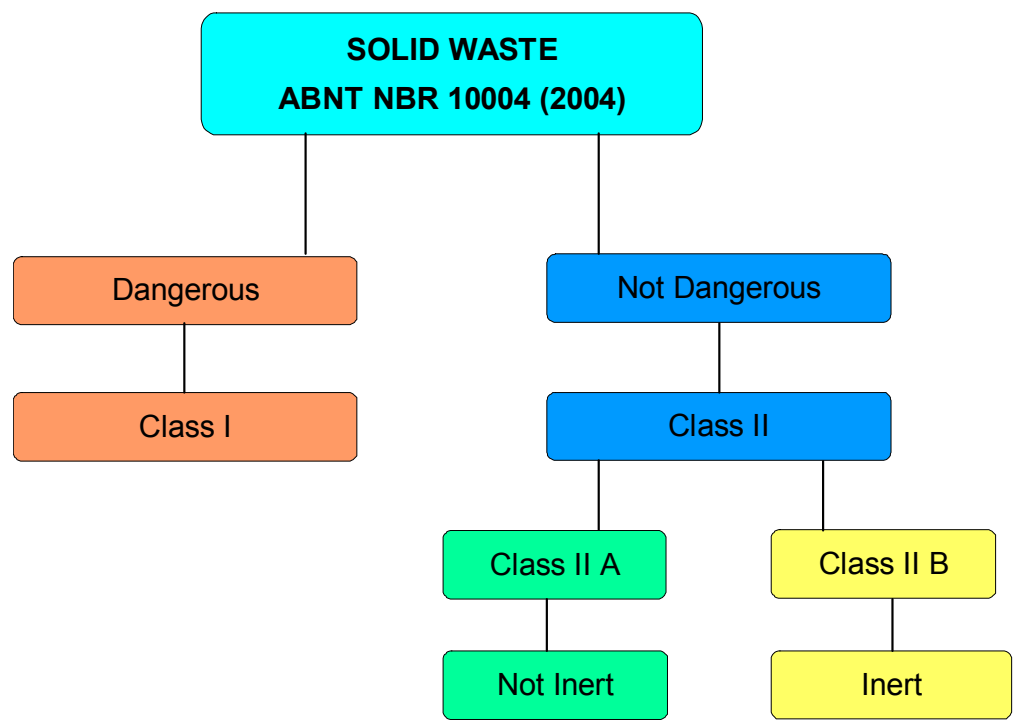

Figure 1. Flowchart of waste classification

Source: ABNT-NBR 10004 (2004).

As shown in Figure 1, the classification of solid waste is a very important and useful tool for industrial waste management and through the Regulatory Norm NBR 10004 it helps defining the waste hazardous and, consequently, the correct destination for its disposal. It is perceived that regarding industrial waste, a special attention has been given to the hazardous waste, once they became a threat to the environment and public health (Song et al., 2014).

New businesses focused on waste management arise every day. Opportunities are in the business of collection and transportation of waste, as well as in the waste processing companies. Also, there are companies that manufacture equipment for recycling of all kinds, such as buckets, bins, defragmenter papers, presses and containers. Sustainable development requires to reuse all material removed from the environment.

\subsection{Waste Disposal}

The company which generates the waste should be responsible for the separation between hazardous and ordinary waste. Siqueira (2001) is concerned that after the identification and separation, the waste must be placed in appropriate containers, so that it can be taken to its collection, treatment and disposal, according to their characteristics.

Bundela et al. (2010), who performed a study about waste in India, in most cities there, show that the municipal solid waste process is limited only in waste generation collection, transportation and disposal, becoming very expensive due the growth of urban centers. It seems that there is a similar problem in Brazil, since the cities are becoming bigger and bigger and it requires better infrastructure and maintenance. In this sense, Barbieri (2004) agrees that the environmental management is a responsibility that must be shared by the State (government), private companies and society.

To Siqueira (2001), the internal collection that is held within the local generator of the waste, which consists on the collection of garbage from the trash can, the closing of the containers and transportation to the specified 
place for storage until they make the external collection. Storage is the temporary custody of the waste, until the external collection is made. The author has identified that the vehicles used to transport the waste also have certain specifications and permits from the relevant authorities, including regular inspections, so that there will be no problems until the final disposal of the waste.

As Valle (1995) has observed, the provision in landfills, which can be classified as sanitary or industrial is the indicated solution for non-hazardous, low moisture content and containing no values to recover stable waste. To meet the demands imposed by environmental legislation, the criteria for landfill projects were redesigned with the introduction of new techniques to reduce the risk of leaks that can contaminate soil and water table.

According to NBR 8419/92 of the Brazilian Association of Technical Standards (ABNT), sanitary landfill is the disposal of municipal solid waste technique in the soil without causing damage to public health and to their safety, minimizing environmental impacts, being the method that uses engineering principles to confine the solid waste to the smallest area possible and reduce them to the smallest allowable volume, covering them with a layer of earth at the conclusion of each workday or at shorter intervals, if necessary. Figure 2 represents a sanitary landfill.

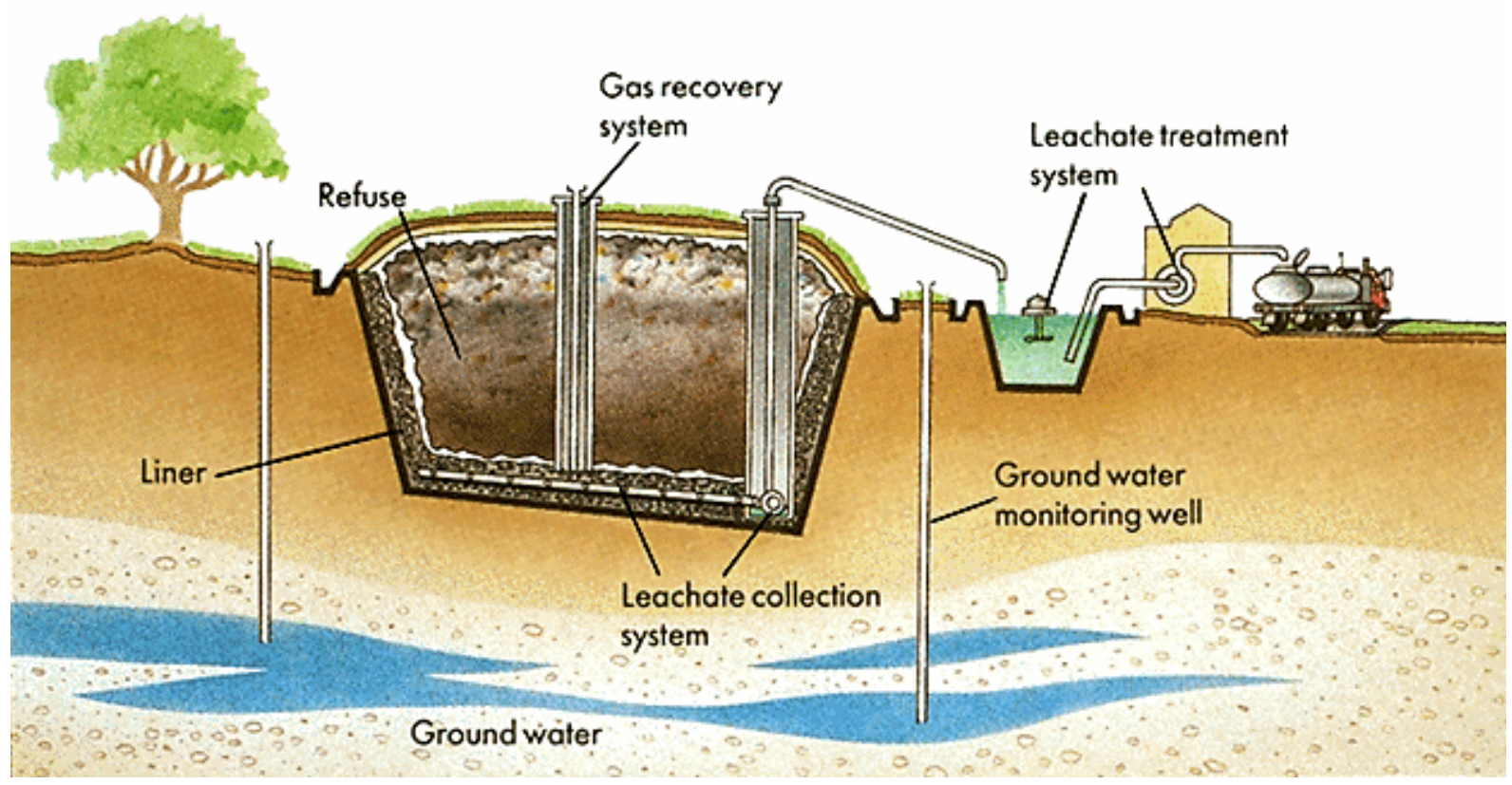

Figure 2. Representation of a sanitary landfill

Source: http://www.oocities.org/green_juris/landfil.html.

So it can be assumed that the landfill is the most appropriate way to dispose of solid waste, however there are great difficulties in its implementation, often due to the high cost of operation, which requires suitable liquid and gas effluents treatments, waterproofing systems, and all kinds of care provided in the technical standards.

\subsection{Environmental Legislation}

Carroll (1979) presented four categories of business that a socially responsible company should cover: economic (producing goods or services and generating profit), legal (social contract, laws and regulations), ethics (non-regulated behavior) e discretionary (voluntary). It is noticed that the legal branch is not necessarily the main one, but it is an important part, so that the supervisory institutions have means to monitor, and the companies have a clear idea and can follow what is considered correct by the law.

Environmental laws clarify the obligations of public authorities, and most of the time just takes some position at being pressured by society. This pressure is impacting directly on the Brazilian environmental law, which is increasingly gaining ground in the legal academic banks. According to Kum et al. (2004), legal factors strongly influence the waste management.

Brazilian environmental legislation is one of the most complete of the world, and besides not being complied in the proper way; the environmental laws are very important and can ensure the preservation of the great 
environmental heritage of the country (Nascentes, 2013). The Environmental Law is a powerful tool at the disposal of society, so that it upholds the rights constitutionally guaranteed to every citizen to live in dignified conditions of survival, a healthy and ecologically balanced environment.

To the State of Rio Grande do Sul (state in the south of Brazil where the research was conducted - initials: RS), Associação Brasileira de Empresas de Tratamento de Resíduos - ABETRE - (2014) is the agency that manages the waste in the following laws, decrees and ordinances, as observed in Table 2.

Table 2. Environment management legislation in Rio Grande do Sul - Brazil

LAWS AND DECREES

Law 7.877, of December 28, 1983

Law 9.921, of July 27, 1993

Law 10.099, of February 07, 1994

Law 13.533, of October 28, 2010

Law 13.761, of July 15, 2011

Decree No. 38,356, of April $1^{\text {st }}$, 1998

FEPAM Ordinance No. 16 of

April 26, 2010

\section{PROVISION REGARDING THE LAWS AND DECREES}

Arranges about the transport of dangerous goods in the State of Rio Grande do Sul and other measures.

Arranges about the management of solid waste, in accordance with Article 247, third paragraph of the State Constitution, and makes other provisions.

Arranges about the solid waste from health services and other matters.

Establishes standards and procedures for recycling, management and disposal of e-waste and other measures.

Establishes the State Technical Register of Potentially Polluting Activities or Use of Environmental Resources, part of the National Environmental System - SISNAMA (Sistema Nacional do Meio Ambiente)-, Rate Control and Environmental Monitoring - RS-TCFA (Taxa de Controle e Fiscalização Ambiental) - according to Federal Law No. 6938 of August 31, 1981 and changes, and other matters.

Approves the Regulation of Law No. 9921, from July 27, 1993, which governs the management of solid waste in the state of Rio Grande do Sul. Arranges about control of final disposal from Class I waste with flammability characteristics of the soil, in systems of final disposal called "Class I landfill waste" and "receiving central and Class I waste disposal" under the State of Rio Grande do Sul.

Source: ABERTRE - Associação Brasileira de Empresas de Tratamento de Resíduos (2014).

Despite the legislation being considered modern, it is essential to have a stricter and more frequent monitoring, so companies need to be aware and currently update the documentation. As an example, a producer of paper and pulp emphasizes actions to continually improve products and services, as well as control and monitor the impacts of their operations on the environment. For that, the organization offers programs focused entirely on environmental control, where the main business focus is to maintain harmony between efficiency in industrial production and the preservation of natural resources (Hoff, 2008).

Another example that can be cited refers to solid waste generated by Tramontina companies, located in the mountain area (known as Serra Gaúcha) of Rio Grande do Sul. The waste go to the Industrial Waste Central. The process involves scrap waste, hazardous waste and non-hazardous. The recyclable scrap is sent for screening, selecting and baling, according to the type, and are destinated to future trades. The wastes that may pose some risk to the environment are deposited in the Landfill of Hazardous Industrial Wastes, while those which do not exhibit toxicity are placed in Class II Landfill. The construction of embankments follows engineering projects so that there is no risk to the environment. Currently, new landfills are larger in an area of basalt exploration activity. With their waste, Tramontina form a new layer of landfill to recover the natural relief of the area. Altogether 42 ditches will be constructed for non-hazardous waste and 26 for hazardous waste. All properly controlled to protect the environment for the next 120 years. 
It is important to note that it is the obligation of the agency responsible for providing the Environmental License to assist the entrepreneur for their suitability to the legislation, as it is the obligation of enterprises to suit up to the requirements of regulatory agencies.

\subsection{Organizational Culture and Implications for Business Practice}

Given that culture is vital for organizational development, understanding that people relate to and guide the organization as a result of the perception of the dominant culture (Schein, 1992), the perception of culture becomes crucial to analyze the organizational dynamics and their constituents. To verify the perception of administrative culture of the organizations, it is essential to know the key concepts of culture and whether they provide sufficient theoretical information to identify the cultural traits of organizations.

Gomes (2004) considers the organization as a set of people, tools and information organized to achieve their goals. The organization is made up of ideas, actions, thoughts and decisions of different people, which give meaning and life to its existence by applying its principles and management practices.

Organizational culture, argues Mintzberg et al. (2000), is the foundation of the organization. It is a set of common beliefs that reflect the traditions and habits, as well as more tangible demonstrations, stories and symbols. For the author, the strength of a culture is to validate the beliefs and shared among members of an organization values, organizational culture would not exist without people.

As organizations grow, they become more complex. They operate in an unstable environment and need to develop systems and procedures that help controlling and guiding their actions (Daft, 2003). For Fleury (1987), the culture, which is the set of values and beliefs, must be consistent with other organizational variables such as structure, technology and leadership style; and the success of the organization depends on these various factors.

Schein (1992) defines the organizational culture as a pattern of basic assumptions that groups develop to deal with the problems of external adaptation and internal integration, these assumptions would be taught to other members as the correct way to perceive, think, and feel in the organization. The author divides organizational culture into three levels as provided in Table 3.

Table 3. The three levels of organizational culture

\begin{tabular}{ll}
\hline \multicolumn{1}{c}{ LEVELS } & \multicolumn{1}{c}{ SPECIFICATIONS } \\
\hline Artifacts and Creations & Involving technology, art, models of visible and audible behaviors. \\
Values & $\begin{array}{l}\text { Consciousness, to a high degree. } \\
\text { Relation with the environment, nature of reality, time and space, the nature of } \\
\text { human activities, the nature of human relationships. }\end{array}$ \\
\hline
\end{tabular}

Source: Adapted from Schein (1992).

People should identify with the company and their work environment to maintain a high level of motivation. The organizational climate has a great influence, because the people's performance depends on the satisfaction with work (Knapik, 2008). Thus, it is necessary that managers understand the importance of organizational culture, as perceived by the employees, and along with them create an environment governed by the innovative vision and focused on legality, productivity, quality and organization of company.

\section{Materials and Methods}

This is an exploratory research, which, for Diehl and Tatim (2004) aims to provide greater awareness of the problem in order to make it more explicit or build hypotheses. For this work, there was investigation in research sites, articles, journals and books, aimed to build the theoretical foundation and the collection of data and information to managers and employees in the organization studied were conducted.

The research was conducted in a qualitative way, that the understanding and Diehl and Tatim (2004) is an approach that can describe the complexity of a given problem and the interaction of certain variables, understand and classify the dynamic processes experienced by social groups, contribute to the change of given group process and enable a greater level of depth, understanding of the peculiarities of the behavior of individuals.

The object of the study is a medium-sized printing industry located in the city of Serafina Corrêa, in Rio Grande do Sul, Brazil, aiming to propose actions for the internal organization and awareness of professionals to enable better management of the waste generated by it. The data collection for this research was conducted through an 
interview with a manager in charge of Personnel Management and the Environment in Alban, Crema \& Cia Ltda. company. A questionnaire containing four questions, which sought information regarding solid waste produced by each sector (pre-printing, printing, finishing and expedition), packaging, storage and final disposal of the waste was applied.

Finally, to analyze the data collected, the technique used for the interpretive analysis, considered by Triviños (1987) a method that allows the analysis of data collected in the light of the review of selected literature about the theme.

\section{Presentation and Discussion of Results}

\subsection{Characterization of the Company Studied}

Operating in the market since 1960, the printing industry Alban, Crema \& Cia Ltda. is familiar and medium-sized company, which stands out for its potential in commercial printing, working at the national level, but especially in the State of Rio Grande do Sul, Brazil. Over the years, it has been conducting ongoing work, providing quality services and acquiring a solid concept with customers, suppliers and employees.

The beginning of its activities was in the rear of the residence of one of the founding partners, Pasqual Alban, on Miguel Soccol Avenue in Serafina Corrêa, Rio Grande do Sul, Brazil. Nowadays, the head office works in its own office on White Castle Street, in the same city.

The building, with more than two thousand square meters of built area, possesses modern facilities and the latest equipment. The company counts with 140 employees in order to meet the needs of the market and customers. Besides the matrix, it has two branches, also located in the city of Serafina Corrêa-RS and an office in Porto Alegre-RS (capital city of the state), in order to better serve customers and advertising agencies.

The company's focus is directed to the creation of products such as catalogs, calendars, notebooks, folders, booklets, constantly advertising the brand customers, within the philosophy of upgrading and technological development, developing new processes and seeking new materials with quality and social responsibility.

\subsection{Current Situation of Waste Management in the Studied Company}

The graphic arts industry Alban, Crema \& Cia Ltda. company generates liquid effluent and solid waste. The objective of this research was the identification of solid waste generated by the industry to prepare actions for the internal organization and awareness of professionals to enable better management.

Figure 3 shows the flowchart of generation of liquid and solid industrial waste per sector of the company.

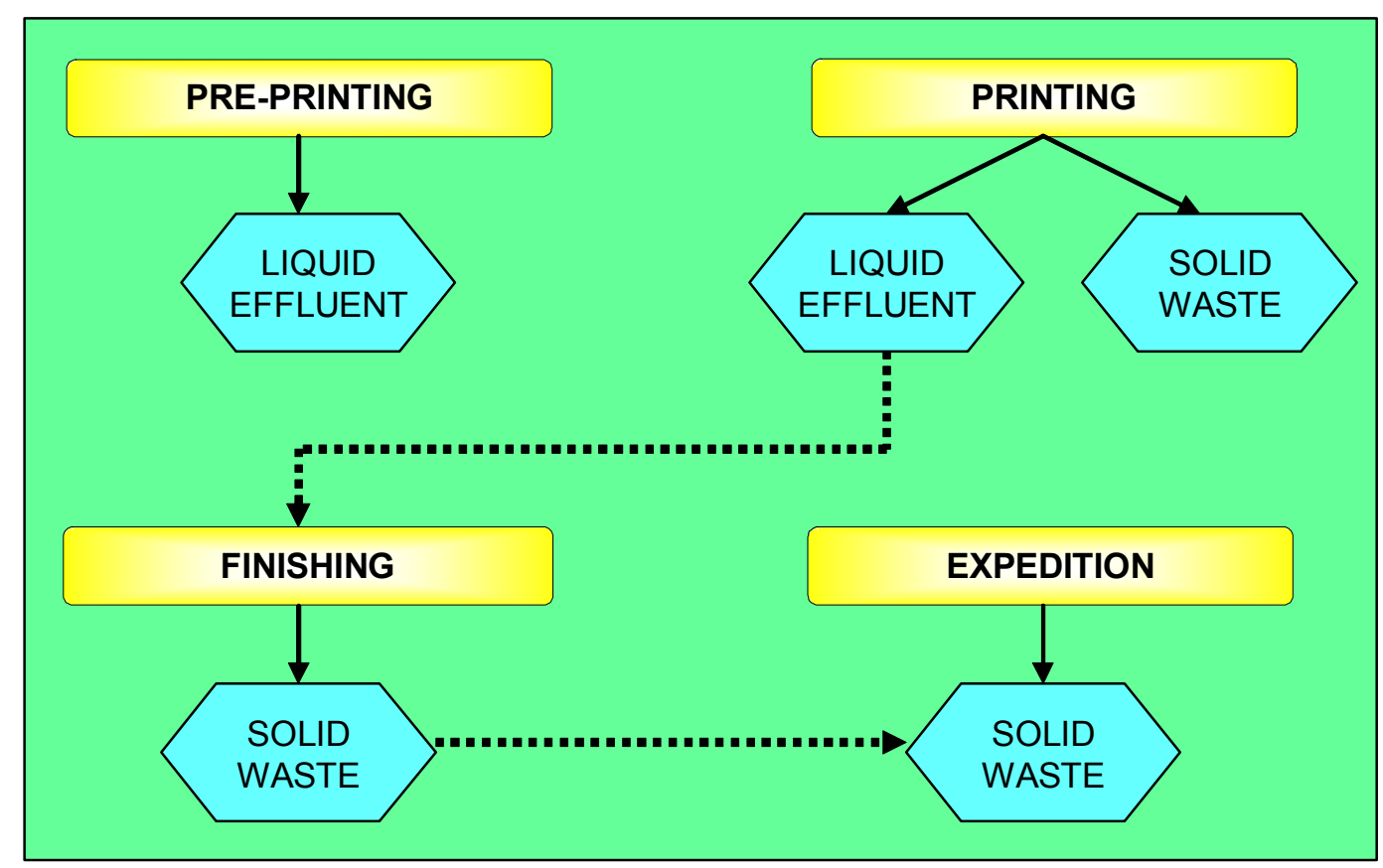

Figure 3. Flowchart of the generation of effluents and waste in the company operations

Source: Data provided by Alban, Crema \& Cia Ltda. (2013) 
It is observed in Figure 3, that the pre-printing sector only generates liquid effluents, while the printing sector generates liquid effluents but also solid waste; and the finishing and expedition sectors generate only solid waste. The sectors of printing and finishing are the ones that generate the biggest amount of waste in the industry, and the largest number of employees of the company is concentrated on these two sectors (printing and finishing).

In Table 4 it is identified the types of solid waste generated by the industry, which are sent or collected by licensed companies by Fundação Estadual de Proteção Ambiental (FEPAM), the agency that controls environmental issues in the state of Rio Grande do Sul, which is given its final disposal by recycling or landfill.

Table 4. Industrial waste generated by the company

\begin{tabular}{|c|c|c|c|c|}
\hline WASTE KIND & $\begin{array}{c}\text { UNIT OF } \\
\text { MEASUREMENT }\end{array}$ & STOWAGE & STORAGE & DESTINATION \\
\hline $\begin{array}{c}\text { Contaminated textile waste } \\
\text { (rag cloths) }\end{array}$ & $\mathrm{m}^{3}$ & Plastic bags & $\begin{array}{l}\text { Open roof area with } \\
\text { impermeable floor }\end{array}$ & Waste Center \\
\hline $\begin{array}{l}\text { Contaminated empty } \\
\text { containers }\end{array}$ & $\mathrm{m}^{3}$ & Plastic bags & $\begin{array}{l}\text { Open roof area with } \\
\text { impermeable floor }\end{array}$ & Waste Center \\
\hline Cardboard Paper waste & $\mathrm{T}$ & Container & $\begin{array}{l}\text { Closed area with } \\
\text { impermeable floor }\end{array}$ & Recycling \\
\hline $\begin{array}{l}\text { Plastic waste (films and } \\
\text { small packages) }\end{array}$ & $\mathrm{T}$ & Plastic bags & $\begin{array}{l}\text { Closed area with } \\
\text { impermeable floor }\end{array}$ & Recycling \\
\hline Textile materials waste & $\mathrm{m}^{3}$ & Plastic bags & $\begin{array}{l}\text { Open roof area with } \\
\text { impermeable floor }\end{array}$ & Waste Center \\
\hline Wood (pallets leftover) & $\mathrm{m}^{3}$ & Bulk & Roof area & Recycling \\
\hline $\begin{array}{c}\text { Nonferrous scrap metals - } \\
\text { sheet }\end{array}$ & $\mathrm{Kg}$ & Pallets & Roof area & Recycling \\
\hline
\end{tabular}

Source: Data provided by Alban, Crema \& Cia Ltda. (2013).

The total of waste generated by the industry is not highly dangerous, not contaminating the environment and people, because the company really strives to properly follow what is provided by the law. The most generated waste is paper and cardboard in the printing and finishing sectors in the company. It is packaged in the container on the outside where it is collected every day by the company responsible for recycling, along with plastic waste. The paper waste can be classified into white paper and waste paper. The white paper is what was not printed and waste paper is the kind of paper that contains printing.

Called chips, waste paper are separated by white and mixed, and then they are collected by the responsible company, recycled and returned to the market as new usable products to consumers such as toilet paper, paper bags, gift packaging, toy products, among others.

Textile waste and empty containers are placed in plastic bags and stored in a covered area with impermeable flooring to the company responsible for the collection, which will give the proper disposal of materials, issuing a Certificate of Final Destination, which is the guarantee of a proper process.

The company is evaluating the possibility of performing their disposal of waste through co-processing, ensuring complete destruction of waste, as a means to prevent future problems from occurring, since this company, even if it is doing the correct destination, in case it encounters a problem in landfills, even possessing certificates of disposal, they sympathize with it.

For the remains of woods that are packaged in bulk and metal scraps that are palletized, these are stored in a covered area on the premises of the industry until the collection by the company responsible for recycling is done.

\subsection{Reflections of Organizational Culture at the Destination of the Waste}

Successful organizations are creating training programs, implementing planning processes and developing ideas that consider human resources as their biggest investment. It is noted that this type of attitude is adopted in companies in which the vision of the administration is more open, where people's commitment results in success. 
The company studied is family ownership since its founding and is currently on the second generation. There are employees performing the same functions since the beginning of the activities, contributing to the company's success. With this, it is seen a stable environment where the attitude is "we do it this way because we have always done so," a vision resistant to change, without perception that doing differently could mean doing it more efficiently. The waste management system is influenced by several factors, such as socio-cultural ones, once the system is considered complex (Kum et. al, 2004).

By analyzing the current scenario, the probability of a third generation taking control of the organization is almost zero, which shows totally opposite to the thought of the second generation in office. The new generation shows no interest in the business and the search for knowledge, and unlike the current administration that even without academic training spares no effort in the pursuit of business growth.

In the current situation, it can be noted by the survey that employees are not motivated on the organization of the company, since leaders have no qualifications or knowledge to be able to require his subordinates an attitude focused on waste management. Thus, it becomes necessary to first qualify for awareness, and subsequently initiate an environmental management. Otherwise, without the interest of the entire organization, starting from the board for employees, there will never be any change.

When an employee is noticed and recognized for his work, he will do his best to have new opportunities, aiming for its growth, the company remains organized, increasing throughput, enabling the administrator to achieve its main objective, which is the profit.

The means of communication play an important role in changing government policy, reinventing methods of global industrialization, increasing speed of change in environmental legislation and creating a viable economic base for decisions about environmental awareness, impacting on society. It has been seen in the media that scandals in the release of environmental licenses have provoked outrage by society that values the ethics, because it was found that employees received bribes to expedite the Environmental Permits, and these were released without inspection and inappropriate areas. It is noteworthy that in the face of the company surveyed have sent documentation to release the Environmental License of its subsidiaries for almost a year, but so far received no response from the competent bodies.

In the studied company, there was great concern about the legislation, but falling short in the internal organization of waste disposal and lack of commitment on the part of employees, since this problem occurs due to lack of training and knowledge regarding environmental issues.

\subsection{Awareness Actions of Proper Disposal of Waste}

Currently the awareness of people towards the proper disposal of waste is a requirement, because of the damage it can cause to society as a whole. It is a challenge to humanity to promote sustainable development quickly and efficiently, but necessary regardless of the difficulties. Natural resources are becoming scarce, the population growing out of control and the environmental impacts increasingly warn that man must begin to understand that nature can not be manipulated.

It is understood that awareness is to show people what the risks are that certain actions might cause, and with simple measures it is possible to show what are the duties and actions that must be performed, requiring that these attitudes become a habit in the organization, not only by staff, but mainly by managers, who should serve as an example.

There are various ways of providing awareness, occurring in written form, with the dissemination of flyers or in the form of lectures, seminars, competitions, also providing recognition developed not only in the organizational environment, but in society volunteer activities. These activities must become fundamental in companies that aim at sustainability, because to remain high in the current market, it is essential to seek differentials and concern for the environment and the value of employees nowadays are key elements for the growth of the organization.

It is important to highlight that there must first be awareness of managers, so that they know how to delegate tasks and lead their teams. People, when they are valued, work better and are no longer mere production to become the great advantage of organizations, such agents should be the focus, as their success or failure depend on the people who work there and if they are not valued, they will not bring profit, nor will they be competitive differentiators.

Another important factor that should be mentioned refers to the quality of life of employees, essential for a company to be healthy in every way, conveying a positive image to society, seeing the success of this company, also through its staff. This achievement can occur investing in deploying reserved to rest, relaxation and physical activities, healthy meals with cafeteria spaces, which provides benefits such as reducing the rate of removal of 
employees, bouts of stress, dissatisfaction and irritation, improved interpersonal relationships, that affects not only the staff, but the entire organization performance.

\section{Final Considerations}

This research aimed to propose actions for the internal organization and awareness of professionals to enable better waste management in Alban, Crema \& Cia Ltda. company, since it is known that the lack of Waste Management System helps to ensure that the actions are not made in an organized manner and pose risks to workers and society.

Some shortcomings when compared to other companies and confronted with the literature review were noted, these failures were observed in organizational culture, personnel and material industry. Moreover, it was noticed that the industry is very structured regarding technology, building structure and logistics. An aspect to be addressed is focused on organizational culture that complicates the deployment of new working practices where management is focused on legislation and is resistant to release funds to the internal organization of the provisions of the waste and the training and upgrading of staff.

In developing this research, there were difficulties regarding the lack of knowledge of managers, which caused dissatisfaction in relation to the current context in which the company is, since, because it is an organization that is among the best graphics of the state of Rio Grande do Sul, Brazil, it should have a more current culture, focused on sustainability that is what is being searched nowadays.

Given the above, it is necessary that the company in the near future, seek awareness techniques, starting with the managers, extending to the other employees of the organization. Faced with this new approach, it will be possible to develop activities aimed at better organization of the personal development of the company and consequently with respect to the environmental management.

Therefore, there will be significant result with simple measures, such as waste collectors identified so that people can make the proper separation of it, thus speeding the process of collection; seek partnerships with recyclers that the waste can be reused, this is also a way of earning profit. Currently the company pays for that waste to be collected; however, there is the possibility of selling these materials that could certainly cause less damage to the environment instead of being disposed of in landfills. And still, after recycled return to the market, which will benefit consumers, which is a form of reverse logistics.

It was observed that, in the course of this research, some changes have already occurred; some developers are taking more care about themselves, using protective equipment and waste disposal. An external space that was presenting irregularities has already been arranged appropriately.

The objective of this research was not fully achieved due to some limitations, which have been mentioned above, but it was noted that the changes are not difficult to be followed, it is necessary goodwill, interest, knowledge and teamwork, such elements that are fundamental in order to obtain success in an organization.

\section{References}

ABETRE - Associação Brasileira de Empresas de Tratamento de Resíduos. (2014). Legislação. Retrieved from http://www.abetre.org.br/biblioteca/legislacao/legislacao-de-referencia-em-residuos-solidos-e-areas-contami nadas\#estadual---rio-grande-do-sul

ABNT NBR 10004. (2014). Resíduos sólidos - Classificação. Retrieved from http://www.aslaa.com.br/legislacoes/NBR\%20n\%2010004-2004.pdf

Barbieri, J. C. (1965). Gestão Ambiental Empresarial: modelos e instrumentos. São Paulo: Saraiva.

Bundela, P. S., Gautam, S. P., Pandey, A. K., Awasthi, M. K., \& Sarsaiya, S. (2010). Municipal solid waste management in Indian cities - a review. International Journal of Environmental Sciences, 2(4). Retrieved from http://www.ipublishing.co.in/jesvol1no12010/EIJES2016.pdf

Carroll, A. B. (1979). A three-dimensional conceptual model of corporate performance. The academy of management review, 4(4), 497-505. Retrieved from http://www.kantakji.com/media/3460/z119.pdf

Ceruti, F. C., \& Silva, M. L. N. (2009). Dificuldades de implantação de Sistema de Gestão Ambiental (SGA) em empresas. Revista Acadêmica de Ciencias Agrárias e Ambientais, 7(1), 111-119. Retrieved from http://www2.pucpr.br/reol/index.php/ACADEMICA?dd1=2805\&dd99=view

Coe, N. M., Dicken, P., \& Hess, M. (2008). Global production networks: realizing the potential. Journal of Economic Geography, 8(3), 271-295. Retrieved from http://joeg.oxfordjournals.org/content/8/3/271 
CONAMA. (2014). RESOLUÇÃO CONAMA nº 306, de 5 de julho de 2002. Estabelece os requisitos mínimos eo termo de referência para realização de auditorias ambientais. Retrieved from http://www.mma.gov.br/port/conama/legiabre.cfm?codlegi=306

Corazza, R. I. (2003). Gestão ambiental e mudanças da estrutura organizacional. RAE-eletrônica, 2(2), 1-23. Retrieved from http://rae.fgv.br/sites/rae.fgv.br/files/artigos/10.1590_S1676-56482003000200011.pdf

Daft, R. L. (2003). Organizações: teorias e projetos. São Paulo: Pioneira.

Dias, R. (2006). Gestão ambiental: responsabilidade social e sustentabilidade. São Paulo: Atlas.

Diehl, A. A., \& Tatim, D. C. (2004). Pesquisa em ciências sociais aplicadas: métodos e técnicas. São Paulo: Prentice Hall.

Donaire, D. (1995). Gestão Ambiental na Empresa. São Paulo: Atlas.

Figueiredo, M. A. G. (1996). O uso de indicadores ambientais no acompanhamento nos sistemas de gerenciamento ambiental. Production, 6(1), 33-34. Retrieved from http://www.scielo.br/pdf/prod/v6n1/v6n1a02.pdf

Fischer, K., \& Schot, J. (1993). Enviromental strategies for industry: international perspectives on research needs and policy implications. Washington, D.C.: Island Press.

Fleury, M. T. L. (1987). Estórias, mitos, heróis - cultura organizacional e relações de trabalho. RAE - Revista de Administração de Empresas, 27(4), 7-18. $\quad$ Retrieved from http://rae.fgv.br/sites/rae.fgv.br/files/artigos/10.1590_S0034-75901987000400003.pdf

Gomes, J. F. (2004). A terceira competência: um convite à revisão do seu modelo de gestão. Rio de Janeiro: Qualitymark.

Hoff, D. N. (n. d.). A construção do desenvolvimento sustentável através das relações entre as organizações e seus stakeholders a proposição de uma estrutura analitica (Unpublished master's thesis). Federal University of Rio Grande do Sul, Porto Alegre, Brazil.

IBGE - Instituto Brasileiro de Geografia e Estatística. (2013). Dados estatísticos. Retrieved from http://www.ibge.gov.br

Knapik, J. (2008). Gestão de Pessoas e Talentos. Curitiba: Ibepx.

Kraemer, M. E. P. (2005). Responsabilidade social corporativa: uma contribuição das empresas para o desenvolvimento sustentável. Revista Eletrônica de Ciência Administrativa (RECADM), 4(1), 1-50. file:///C:/Users/Usuario/Downloads/Kraemer_2005_Responsabilidade-social-corpor_24190.pdf

Kum, V., Sharp, A., \& Harnpornchai, N. (2005). Improving the solid waste management in Phnom Penh city: a strategic approach. Waste management, 25(1), 101-109. http://dx.doi.org/10.1016/j.wasman.2004.09.004

Mintzberg, H., Ahlstrand, B., \& Lampel, J. (2000). Safári de estratégia: um roteiro pela selva do planejamento estratégico. Porto Alegre: Bookman.

Nilsson, W. R. (1998). Services instead of products: experiences from energy markets - examples from Sweden. In F. Meyer-Krahmer (Ed.), Innovation and sustainable development: lessons for innovation policies. Heidelberg: Physica-Verlag. http://dx.doi.org/10.1007/978-3-642-93639-5_6

Schein, E. (1992). Psicologia organizacional. Rio de Janeiro: Prentice-Hall.

Siqueira, A. O. (2001). Resíduos sólidos: da classificação à disposição final. Editorial Racine.

Song, Q., Li, J., \& Zeng, X. (2014). Minimizing the increasing solid waste through zero waste strategy. Journal of Cleaner Production, 1-12. http://dx.doi.org/10.1080/00207543.2014.932929

Triviños, A. N. S. (1987). Introdução à pesquisa em ciências sociais: a pesquisa qualitativa em educação. São Paulo, Atlas.

Valle, C. E. (1995). Qualidade Ambiental: Como Ser Competitivo Protegendo o Meio Ambiente: como se preparar para as Normas ISO 14000. São Paulo: Pioneira.

Widmer, W. M. (1997). O Sistema de gestão ambiental (NBR ISSO 14000) e sua integração com o Sistema de Qualidade (NBR ISSO 9002) (Unpublished master's thesis). Federal University of Santa Catarina, Florianópolis, Brazil.

Zeng, X., Sun, Q., Huo, B., Wan, H., \& Jing, C. (2010). Integrated Solid Waste Management under Global Warming. The Open Waste 
http://dx.doi.org/10.2174/1876400201003010013

\section{Copyrights}

Copyright for this article is retained by the author(s), with first publication rights granted to the journal.

This is an open-access article distributed under the terms and conditions of the Creative Commons Attribution license (http://creativecommons.org/licenses/by/3.0/). 